\title{
3D INTEGRATED SURVEYS AND STRATIGRAPHIC METHODS FOR A DEEPER UNDERSTANDING OF HISTORICAL BUILDINGS. A CASE -STUDY OF THE FRANCISCAN MONASTERY AND THE IMMACOLATA CHURCH IN TROINA, SICILY.
}

\author{
M.T. Campisi, S. Giuliano, M. Liuzzo
}

KORE University of Enna, Enna, Italy, (teresa.campisi, sebastiano.giuliano, mariangela.liuzzo)@unikore.it

\author{
Commission VI, WG VI/4
}

KEY WORDS: Troina, Franciscan Church, Range Based Survey, Image Based Survey, GPS Positioning, Stratigraphic Analysis

\begin{abstract}
:
The study presents the results of the application of a multidisciplinary methodology for a deeper understanding of historical buildings. 3D integrated surveys and stratigraphic methods can together make it possible to date the principle construction and evolution phases of historical buildings for which a thorough historical documentation does not exist for our time.

The case-study presented involves the Franciscan monastery and adjacent Immacolata church in Troina, which is a small medieval town located in the north-eastern part of Sicily.

The small number of historical records has only allowed for the dating of the monastery's foundation and of a few of transformation phases. Contrarily to this, various markings on the surfaces of the walls indicate rather the presence of numerous construction phases.

The inaccessibility of parts of the internal spaces, as well as the existence of a sharp incline of the road and of very high walls along scant sections of the road, are the reasons for having chosen to carry out a $3 \mathrm{D}$ laser-scanning survey campaign. It made it possible to document the overall area and the relationship between the different parts of the complex. The integration between 3D laser scanning and photo-modelling methods made it possible to highlight the details, anomalies, traces and signs of the stratifications over time. The results of this integrated survey were explained in a series of graphic elaborations in support to the following stratigraphic investigation, to put in order the numerous traces discovered.
\end{abstract}

\section{INTRODUCTION}

The Italian territory as a whole, but in particular the Sicilian one, is extremely rich in historic town centres and architectural stratification, due to the numerous interventions and transformations carried out in the distant past. The evolution of these structures are only rarely well documented in a clear and thorough manner. This usually only happens in particular for the most prestigious architectures. For the rest of the buildings, which are just as ancient and noteworthy but considered of minor importance, the possibility of understanding their transformation history is much more difficult. The history of these buildings is told by reading and interpreting the physical signs, the interacting and interfering markings that characterise both the functional and architectural building elements. The act of reading an historical stratified architecture is a delicate operation which has always made it necessary to first break down the real object into a structured network of interpretive models (necessarily partial, simplified and often regulated by knowledge from differing disciplines) and then to put the pieces back together. The end objective is to rebuild the sigle original building but having achieved a high level of understanding.

Today's innovative survey and analysis technology makes it possible to simplify and, at the same time, optimise this process, guaranteeing the possibility to gather a significant amount of data in order to build a single model with an elevated content of information. It's necessary to initiate analytical and interpretive procedures on this model through detailed and synthesis elaborations. These are useful in demonstrating both the complexity and the individual peculiarities of each single investigated object. With this responsibility, the role of a graphic instrument is characterised in two directions.

On one hand, the current survey and 3D representation techniques provide a critical instrument that is able to independently analyse morphological, metric, material and conservation aspects. These are fundamental in the understanding of a complex phenomenon that is investigated. On the other hand though, the same techniques can become an effective instrument in the "interdisciplinary cooperation", when they are capable of interacting and clearly presenting the necessary information to make new specialistic readings belonging to other scientific fields.

In line with this methodological presumption, a multidisciplinary study was carried out one of the lesser known architectural samples of which the Sicilian territory is plentiful. Up until now, no systematic and in-depth investigations had been conducted on this site, which includes both the Franciscan convent and the ancient Immaculate Conception church in Troina. ${ }^{1}$

\footnotetext{
${ }^{1}$ CREDITS - M. Liuzzo: Introduction, Conclusions; S. Giuliano: Three dimensional survey campaign; M.T. Campisi: Historical notes, Stratigraphic analysis.

2 The three dimensional survey was integrated with a GPS positioning system. The laser scanning survey operations were carried out with a Leica C10 time of flight laser scanner. This instrument is used by the Survey and Representation Laboratory of the "Kore" University oEnna.
} 


\section{THE CASE-STUDY OF THE FRANCISCAN MONASTERY AND IMMACOLATA CHURCH COMPLEX}

\subsection{Historical notes}

The medieval town of Troina is located in the north-eastern part of Sicily and was founded by the Greek. It eventually became an important Byzantine centre from the VII up to the IX century $\mathrm{AD}$ when during the Islamic invasion (IX to XI century $\mathrm{AD}$ ) it was conquered. The town then became the first capital of the Norman government during the initial conquest phase in 1061 and the first bishopric in 1081 (Malaterrae, 1928).

Modern chroniclers describe the town has already having a Byzantine fortification and being reinforced militarily on several occasions during Norman rule, especially before 1063 . The historical descriptions available have the area of the fortified citadel coinciding with the area that is delimited, to the east by the former St. Andrew's civil hospital (located in the eastern part of the current Cathedral) and to the south near the current ruins of the ex-Gesù church. These describe the presence of three defence towers and four access doors.

The case study is based on the XV century Franciscan monastery in Troina and its Immacolata church. They are located along the city walls of this ancient town and adjacent to a Norman tower which is thought to be from the XII century. Limited information is known on the building itself aside from a few historical construction phases. The initial foundation phase is recorded as having been built in 1459 and historical sources have placed it in a pre-existing Basilian infirmary (Arona,2013).
The dates of some of the subsequent extensions are known as part of the limited information discovered (fig. 1). For example, a convent extension is dated as of 1650 and the foundation of the Immaculate Conception congregation in a small oratory next to the convent's church, is said to have been done in 1609. The convent, already in decay during the XVIII century, was acquired in 1872 by the municipality and transformed for scholastic use. By 1891 the church was already in a precarious state of conservation, with subsequent damages being reported in later years. For example, in 1930 the collapse of the choir and of a prospectus wall was feared, while later in 1938, the vulnerable state of the dome of the bell tower was reported and it later collapsed causing collateral damages.

\subsection{Three dimensional survey campaign}

The particular conditions of the monument and of the urban area in which it is situated have influenced the choice of survey methodologies (fig. 2). The well consolidated laser scanning survey technology ${ }^{2}$ was chosen as it is the most suitable to produce a three dimensional model with an elevated morphometric level of precision.

The church, in fact, is set within a complex urban fabric that was built from a system of winding roads with significant rises in elevation and surrounded by stairs and ramps. In contrast, the internal configuration of the church is characterised by a simple yet irregular geometric layout of halls with no outlying chapels.

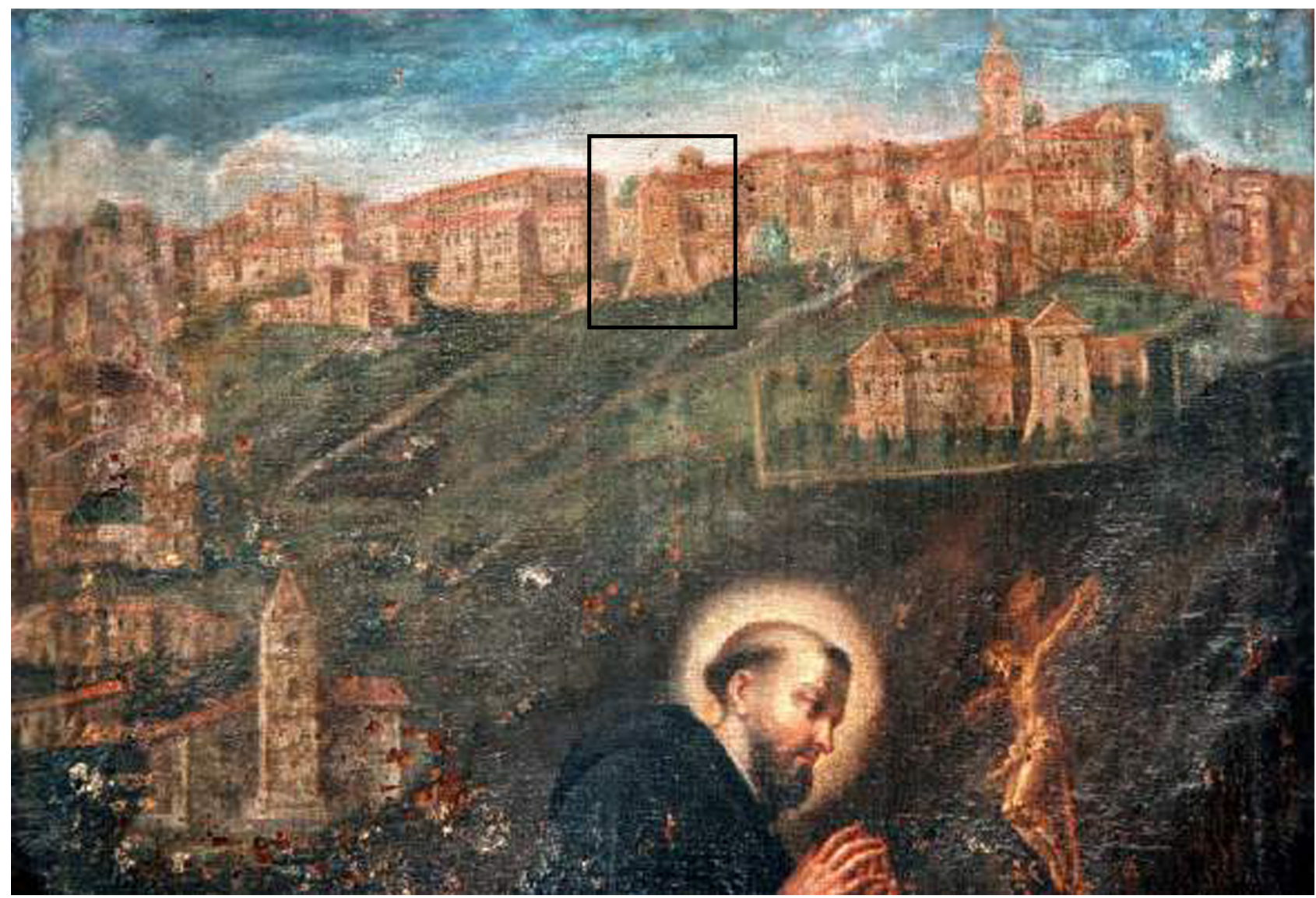

Fig. 1: Representation of the town of Troina in 1700. The image illustrates the south-eastern tower facade of the Convent. San Silvestro Monaco da Troina orante, oil on canvas, c. XVIII. 
Due to the complex articulation of the external spaces adjacent to the church, it was necessary to carryout various scans in order to guarantee the total coverage of the object in study. 3 scans were therefore interconnected for the internal space of the church and 14 scans were used for its external facades. It was therefore possible to reduce the hidden areas because of the presence of numerous obstacles between the front of the church and the laser scanner station points.

The scans include both those carried out on the environment at 360 degrees, in order to document the articulated urban and architectural structure, as well as detailed scans to define the particularly interesting architectural details.

In this case, the survey of the south-western facing front of the church was revealed to be particularly interesting. For instance, the presence of numerous markings on the facade indicate the complexity of the building stratigraphy, while the presence of terracing, at various altitudes and placed against the façade, represents a result of the most recent modifications to the urban street layout. From a cultural point of view, this configuration has created one of the most scrutinised elements of the proposed case study. From an operational-technical point of view, the terracing system has helped in allowing for the placing of the laser scanner survey station at different altitudes.

This helped maintain, as much as possible, a constant distance between the instrument and the facade wall, therefore acquiring a density of points that only vary slightly along the height and width of the facade ${ }^{3}$. This led to a detailed survey, with a fairly constant density in the point cloud, capable of adequately supporting the generating of triangular mesh models and maintaining a uniformed level of detail.

For both this reason as well as the simultaneous photographic survey, that was carried out with the same scanning instrument, it was possible to obtain a model capable of visualising even the smallest partitions in the wall, such as each individual stone of the masonry, for example. For the purpose of this study, this aspect was fundamental in being able to support and validate the reasoning behind the construction phases of the building. Lastly, the survey of the roofs was carried out with image-based technology. The numerous amount of windows on the top floor of the buildings surrounding the church made it possible to take pictures of the roof tops, from different points and at an almost constant distance. These were necessary for the photomodelling procedure, which concluded with the creation of a $3 \mathrm{D}$ point cloud model of the roof and the subsequent integration in the total point cloud of the monument (fig. 3).

Agisoft Photoscan software was used to elaborate three different projects with 33, 9 and 5 respective pictures. It was therefore possible to take advantage in the best possible way, the potentials of the photogrammetric method in relation to the acquisition points of the pictures and to the morphology of the church's facade. The combining of the individual projects, which contained their respective proportions of the
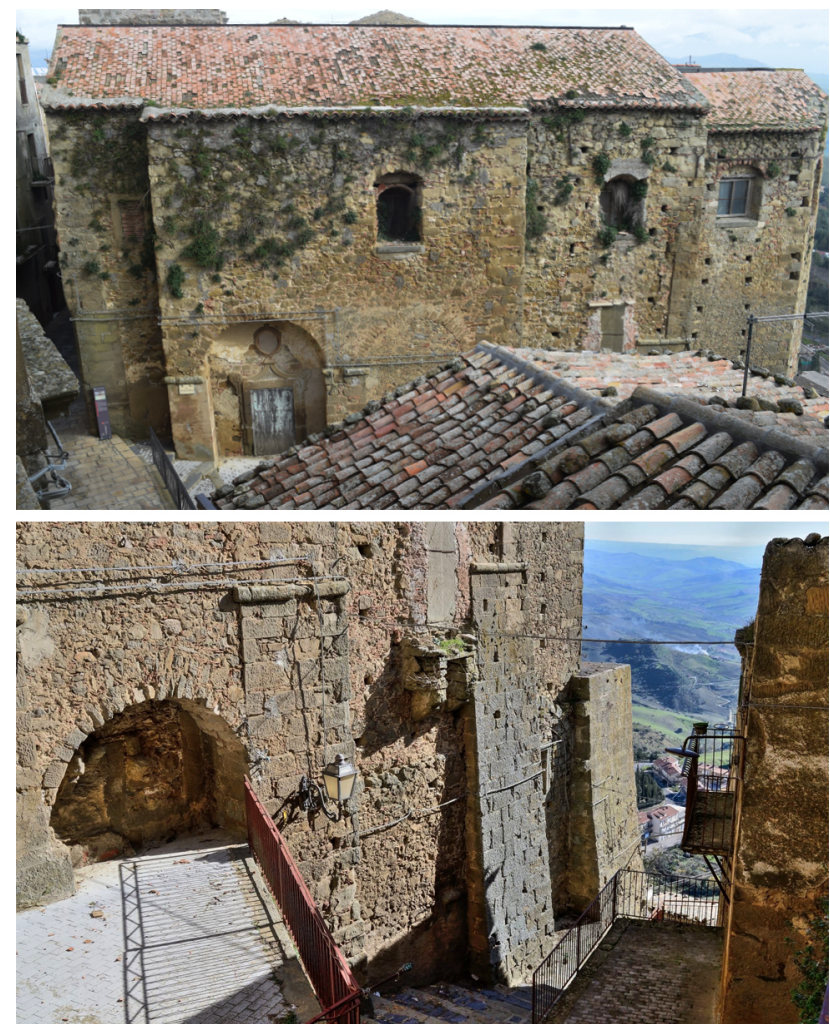

Fig. 2: Conventual complex and urban context.

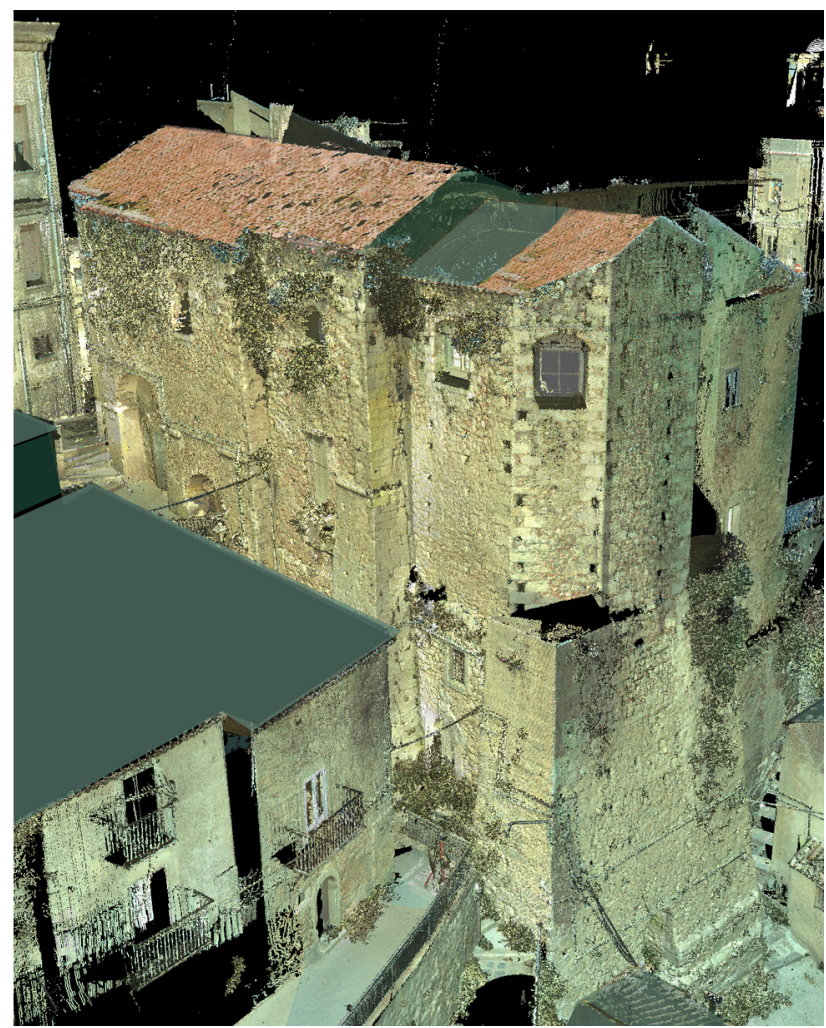

Fig. 3: Aerial view of the 3D model.

3 The laser scanning survey of the facades, characterised by elevated heights that face narrow streets, generally represent the problem of not being able to obtain a uniform distribution of acquired points, especially in the highest and farthest areas from the instrument. 
church's facade and of the south-west facing side of the tower, was possible thanks to the data from the point cloud acquired from the laser scans.

Aside from putting into scale the morphological data obtained through image based techniques, the point cloud model made it possible to verify the reliability of the survey of the church roof by allowing for the overlapping of parts of the object that were surveyed by both technologies.

Partial integrations with the image based method were implemented for the sections of the wall where an elevated geometric and chromatic resolution were necessary. This made it therefore possible to then analyse in detail the markings attributable to various stratigraphic phases.

For the purpose of this research, special attention was placed on the graphic rendering phase of the surveyed object with the idea that the point cloud data would possibly be managed by other technicians involved in the multi-disciplinary study of the architectural complex (figs. 4, 5).

All of the 2D technical representations were created from the export of the model's ortho-images in .tif geo-referenced files. The particularity of these export files is that they maintain an elevated level of definition with regards to the original point cloud as well as the information regarding the geographic positioning of the object.

The individual images were subsequently managed within a CAD platform, thus facilitating the organisation of the following phases of work regarding the study and analysis of the architectural complex and its individual elements (figs. 6, $8)$.

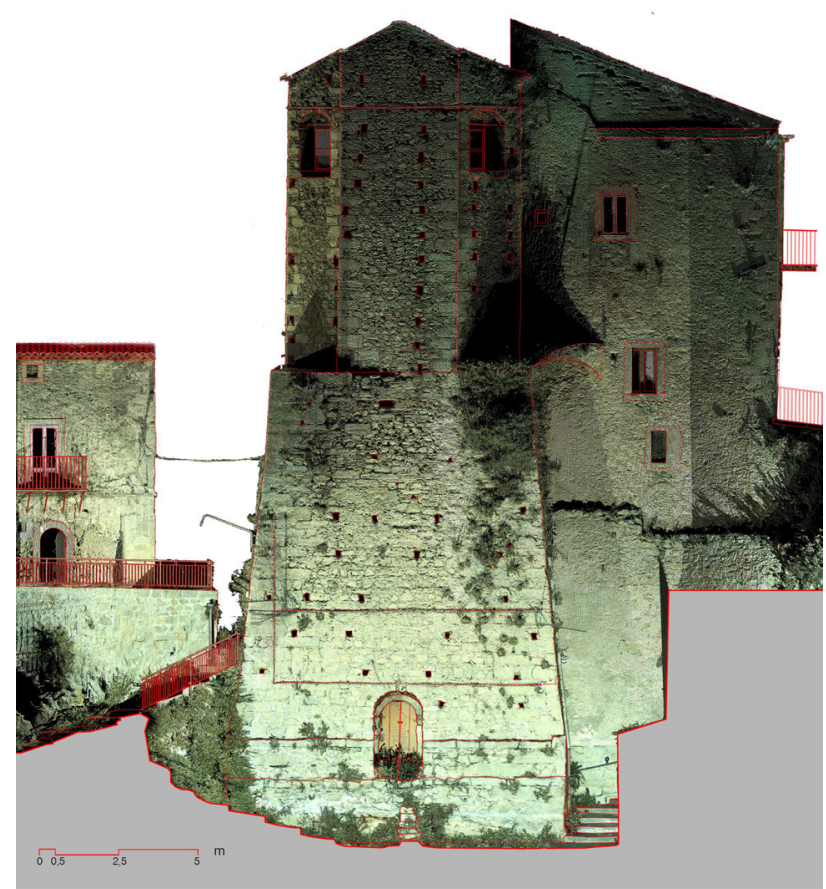

Fig. 4: Orthoprojection of the point cloud model. South-eastern front.

\subsection{Stratigraphic analysis}

The stratigraphic method as applied to architectural surfaces was developed during the second half of the 1970s to the $1980 \mathrm{~s}$, thanks to the fruitful interdisciplinary exchange between archaeology, restoration and archaeometry specialists. The stratigraphic practice has expanded the cognitive fields, taking the research beyond the single building (by means of different types of wall texture, the source of the building materials, the architectural morphologies and construction techniques; the archaeometric investigations) to be able to compare with other buildings and with natural resources. The implementation of building types of already known date can provide an initial macro selection of information as it is so numerous. This will then make the following step of having to select only the most useful data for the objective, much less burdensome.

This type of simplified methodology is much easier to achieve in historical areas that have been involved in studies on the dating of building techniques for long periods of time, while less easier for those other historically geographic areas, such as that which is being studied, in which the application of a dating analysis would represent an initial occasion for classification.

The stratigraphic methodology is certainly an additional instrument of understanding and in any case, a method for a more detailed analysis and for observing 'diagnostic differences' of historical buildings. Its application to the analysis of vertical surfaces of buildings and the goal of preservation of material can, however, constitute a limitation to the scientific objectivity of the method formulated by Harris in 1979 and subsequently applied to architecture. (Doglioni, 1997; Treccani, 1997; Brogiolo, 1988; Boato, 2008)

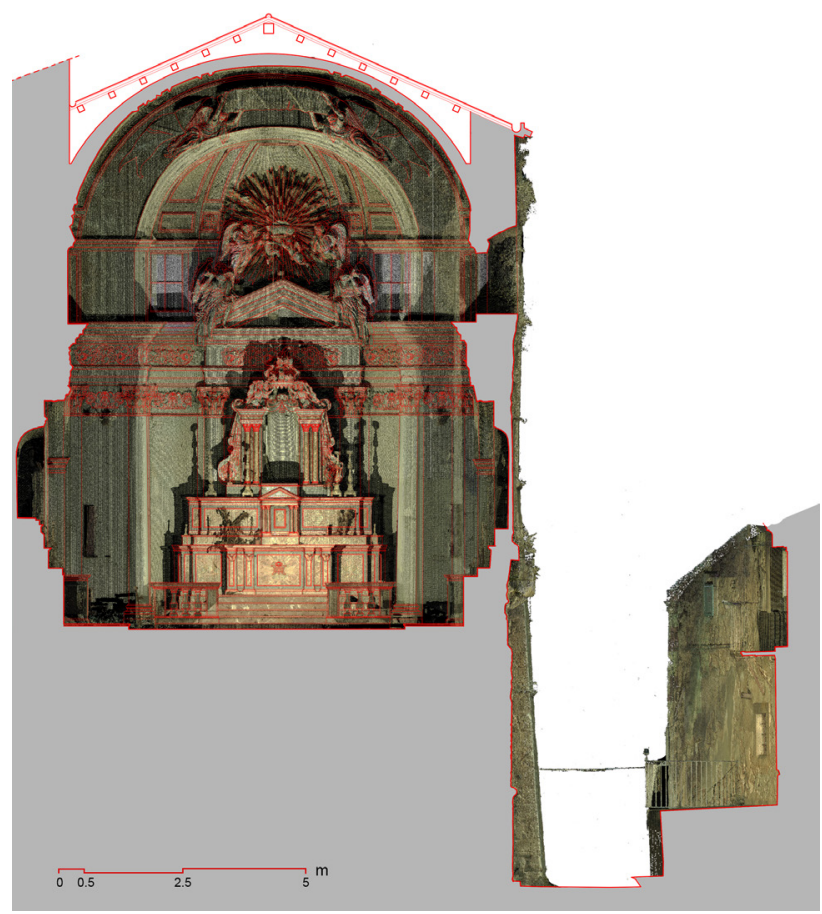

Fig. 5: Orthoprojection of the point cloud model. Transversal section of the church. 

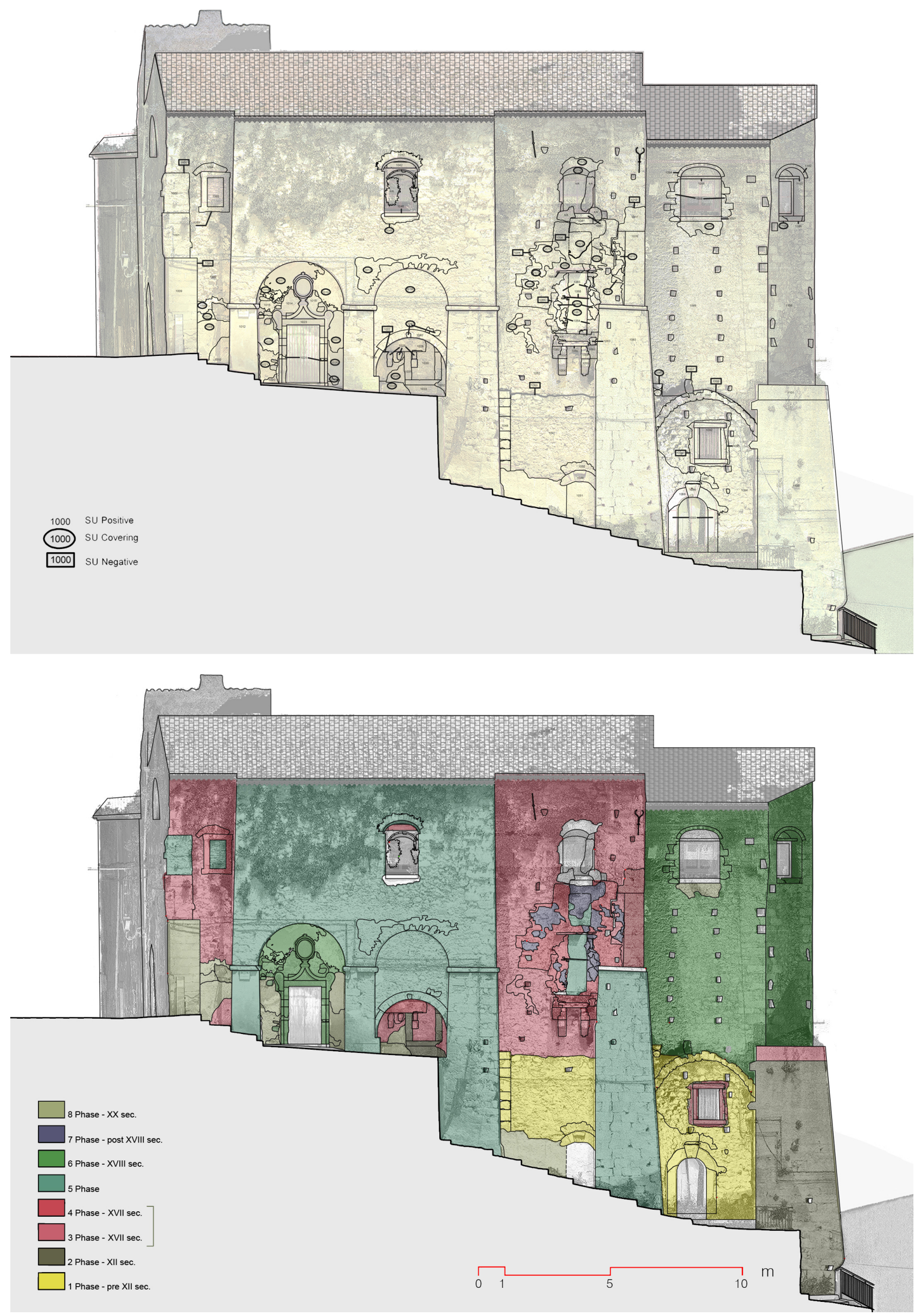

Fig. 6: Stratigraphic reading and representation of the temporal phases on the south-western front of the point cloud model. 
Also in this current study, due to the absence of previous studies and materials, it's difficult to place some stratigraphic units into a particular temporal framework with any certainty. The experimentation has therefore given rise, through indirect relationships (analogical, typological and functional), to configurational hypotheses (Mannoni, Boato, 2002), rather than to exact chronological dating.

The building techniques often presenting sequential constructive successions, are classified according to a relationship of contemporaneity (rather than in stratigraphic succession), by identifying all of the architectural elements useful to reconstruct, in an interpretative way, the connections between the parts that are not in physical sequence, when there is a lack of sufficient data.

In this case, by adopting the logic of replacing the wall stratigraphic unit with the constructive stratigraphic unit, the analysis produces a horizontal periodisation for technologically unitary groups and vertical partitions for units of "technological families" (Treccani, 2000).

The individual SU (stratigraphic units) have thus been identified as "Masonry", "Mortars" and "Windows". The negative units were not loaded into the Harris diagram software, but rather indicated in the graphic representation of the SU.

Stratify 1.5 software was used to obtain the Harris matrix (Herzog, 2008), as it is capable of introducing both direct and indirect stratigraphic relationships and easily managing a considerable amount of data. The resulting diagram was then organised for greater ease in understanding the reports.

This study, as applied to the town of Troina, has made it possible to establish an initial classification of the local masonry techniques, which is useful for future studies on historical buildings. A study has originated from this initial work that seeks to identify various defence structures of the Norman period, using textural typologies and documentary information and it is currently in progress.

In this paper, the south-western and north-western facades of the complex are analysed using the stratigraphic method, while the analysis of the south-eastern facade is still in progress.
The south-western facade of the church indicates numerous and various wall textures that are in both horizontal and vertical sequence as well as in entire building portions (apse). On the same facade some of the constructive elements, such as the stone brackets, are incongruous with a religious building. This might be attributable to the Basilian infirmary phase, or to a civil structure dated between the Norman period and the XV century (during the convent construction period).

The stratigraphic investigation through the Harris diagram development led to the identification of seven sequential phases, with a hypothetical beginning in the pre-Norman period to the XX century (figs. 6, 7), and five masonry typologies (possible phases: pre-Norman, Norman, XVII century, XVIII century). There are also many surviving elements of preexisting configurations (SU 1042).

The stratigraphic investigation on the church's north-western facade and the bell tower has not made it possible to clarify with any certainty several hypotheses, for the presence of many modification and for the continued use of some of the same masonry techniques throughout different spans of time. The bell tower seems to predate the church facade which was built in 1605 , but nevertheless indicating some transformation phases. An initial structure, defined by a basement and its moulded ending, could coincide with the first convent building (XV century). A subsequent elevation seems perhaps simultaneous to the church facade construction, because of the similar stone moulding (SU 2011 and 2023), with an open part, covered with stonework that is comparable to an existing one (SU 2015), in a date that cannot be specified (as evidenced by the T 2000, 2001) (fig. 8). The collapse of the original bell tower dome, after 1938, leaves us with a mutilated structure, therefore limiting a possible hypothesis.

The facade of the church indicates more discontinuous phases, with walls connected to the south-western facade and others are products of subsequent additions or perhaps historical repairs (SU 2027, 2029, 2043). The two main formal elements (portal, SU 2043; arched window, SU 2044) could have different datings, due to the adjoining wall elements.

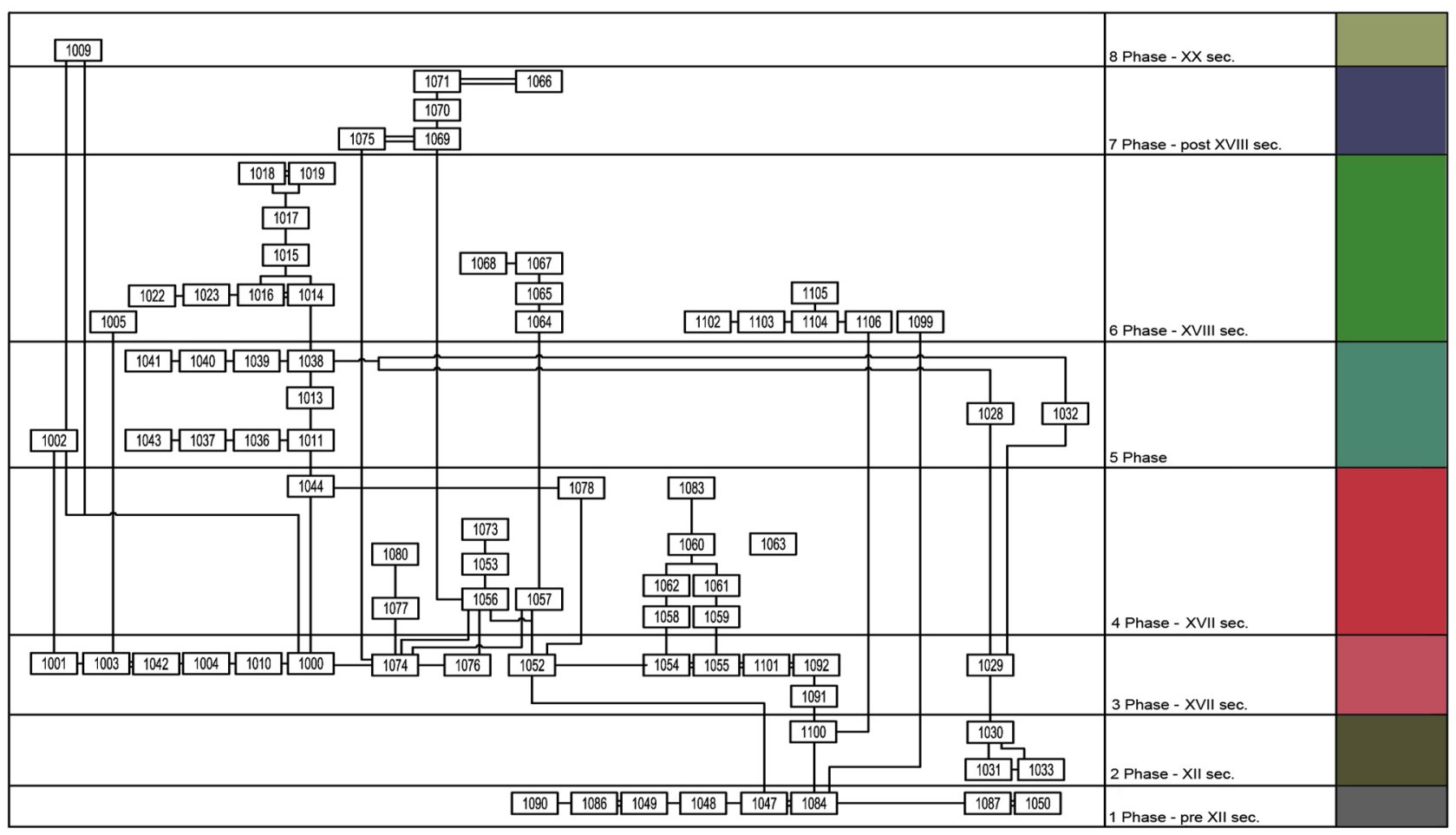

Fig. 7: Matrice of Harris of the south-western front (the negative SUs are not represented). 
The International Archives of the Photogrammetry, Remote Sensing and Spatial Information Sciences, Volume XLII-2/W11, 2019 GEORES 2019 - 2nd International Conference of Geomatics and Restoration, 8-10 May 2019, Milan, Italy
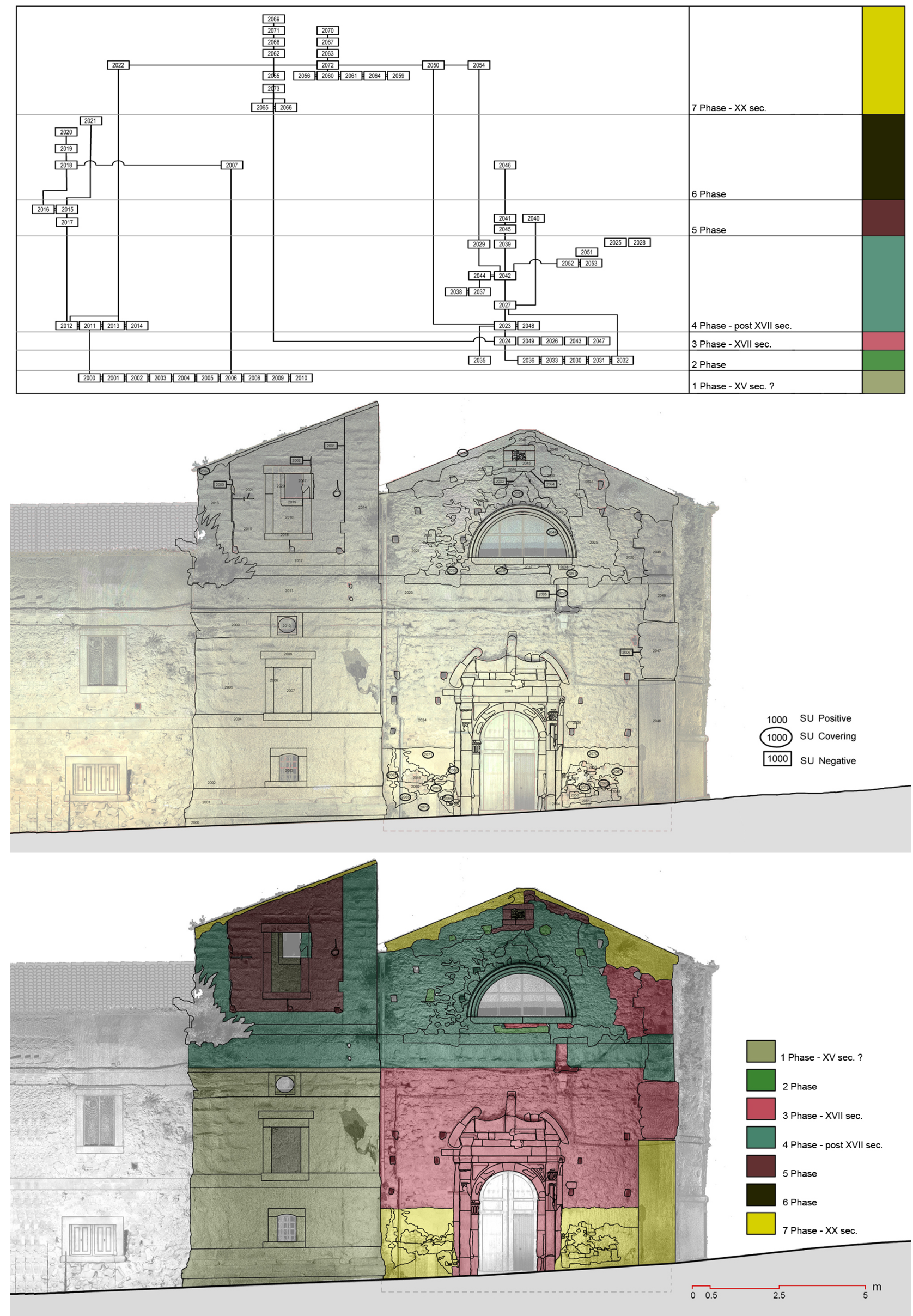

Fig. 8: Matrice of Harris, stratigraphic reading and representation of the temporal phases on the north-western front of the point cloud model. 


\section{CONCLUSIONS}

The work done involved the application of a versatile and efficient multidisciplinary procedure for the study of stratified historical architecture. With the aim of understanding the complex architectural history of the building, even in the absence of thorough historical documentation, we tried to read the building of it through the understanding and classification of the markings present on its surfaces.

Even though the survey techniques and the stratigraphic analysis used are solid research instruments and do not represent any novelty within the scientific field, the study reached interesting results, at least with regards to two different aspects.

In terms of the methodological aspect, the study verified the efficiency in the integrated use of range and image based techniques aimed at obtaining all morphometric, material and chromatic information to support a precise and accurate stratigraphic analysis.

By evaluating the results reached on the Immaculate church of Troina, the temporal sequences recognised on the surfaces of the walls make it possible to move forward with several hypotheses which were previously never made due to a lack of information.

The hope is that the application of these analyses on the other walls of the building, especially on those currently inaccessible, will make it possible to gather a framework of information that will lead to the formulating of exhaustive conjectural hypotheses.

By expanding the interested area to the town and by finally having built an initial classification of the historical building techniques, it can be useful in interpreting other buildings with similar wall textures.

The ultimate goal of this research, extended to the historical centre, could possibly be not only to reach a framework of understanding on individual architectures, but also to study, using new interpretive tools, the historical evolution of the urban structure of Troina.

\section{ACKNOWLEDGEMENTS}

The authors thank Marco Dispinzeri for his contribution in the research activities.

\section{REFERENCES}

Amico, V., 1855-56. Dizionario topografico della Sicilia. Vol. 1. (Translated by G. Di Marzo). Salvatore Di Marzo Editore, Palermo.

Arona, B., 2013. Fra Antonino O.F.M. Capp.Memorie della vetustissima e nobilissima città di Troina. Comune di Troina, Troina (EN).

Baviera Llòpez, E.M., Denia Rìos, J.L., Llopis Verdù, J., Martìnez Piqueras, J.F., 2016. Digitalised metric survey of the laboratories building at Fontilles Sanatorium using three different technologies. In: Bertocci, S., Bini M. (eds.). Le Ragioni del Disegno. Pensiero, Forma e Modello nella Gestione della Complessità. Proceedings of $38^{\circ}$ Convegno Internazionale dei Docenti della Rappresentazione. Gangemi Editore, Roma, pp. 73-82.
Boato, A., Mannoni, T., 2002. Archeologia e storia del cantiere di costruzione. In: Archeologia dell'Architettura, 1, pp. 39-53.

Boato, A., 2008. L'archeologia in architettura. Misurazioni, stratigrafie, datazioni, restauro. Marsilio, Venezia.

Brogiolo, G.P., 1988. Archeologia dell'edilizia storica. Newpress, Como.

Brusaporci, S., 2015. The Representation of Architectural Heritage in the Digital Age. In: Khosrow-Pour M. (eds.), Encyclopedia of Information Science and Technology. Third Edition. Hershey, PA: IGI Global, pp. 4195-4205.

De Luca, L., 2011. La fotomodellazione architettonica. Rilievo, modellazione, rappresentazione di edifici a partire da fotografie. Dario Flaccovio Editore, Palermo.

Doglioni, F., 1997. Stratigrafia e restauro. Fra conoscenza e conservazione dell'architettura. Lint, Trieste.

Harris, C.E., Brown, M.R. III, Brown, G.J., 2014. Practices in Archeological stratigraphy. Academic Press, London.

Herzog, I., Hansohm, J., 2008. Monotone Regression - A Method for Combining Dates and Stratigraphy. Paper presented at the Workshop 12 Archäologie und Computer. Kulturelles Erbe und neue Technologien held in Vienna 2007. PDF file on CD. Phoibos Verlag, Vienna.

Malaterrae Gaufredi Monachi benedectini. Historia Sicula. In: Muratori, L.A., 1928. Rerum italicum scriptores. Zanichelli, Bologna.

Merlo, A., Vendrell Vidal, E., Fantini, F., Sànchez-Belenguer, A., 2013. 3D model visualization enhancements in real-time game engines. In: Remondino, F., Kersten, T., Fuse, T., Gonzalez Aguile, D. (eds.), 3Darch 2013 - 3D virtual reconstruction and visualization of complex architectures, pp. 181-188.

Meschini, A., 2011. Tecnologie digitali e comunicazione dei beni culturali. Stato dell'arte e prospettive di sviluppo. In: DISEGNARECON, 4(8), pp. 14-24.

Mingucci, R., Cipriani, L., Bartolomei, C., Manfredini, A.M., Garagnani, S., 2013. Modellazione integrata per la gestione del progetto di restauro. In Brusaporci, S. (eds.), Modelli complessi per la gestione del patrimonio architettonico-urbano. Gangemi editore, Roma, pp. 66-82.

Remondino, F., 2011. Heritage recording and 3D modeling with photogrammetry and 3D scanning. In: Remote Sensing and Spatial Information Sciences, vol. 3(6), pp. 1104-1138.

Remondino, F., 2011. Rilievo e modellazione 3D di siti e architetture complesse. In: DISEGNARECON, 4(8), pp. 90-98.

Treccani, G.P., 1997. Sull'utilità (e il danno) della stratigrafia archeologica per la conservazione ed il riuso del costruito. In: Ananke, V, pp. 197-201.

Treccani, G.P., 2000. Archeologie, restauro, conservazione. Mentalità e pratiche dell'archeologia nell'intervento sul costruito. Unicopli, Milano. 